\title{
Pemodelan fenologi populasi penggerek batang padi kuning Scirpophaga incertulas (Walker) berbasis pengaruh iklim
}

\author{
Population phenology modeling of rice yellow stem borer \\ Scirpophaga incertulas (Walker) based on climate effect \\ Syahrizal Koem ${ }^{1,2 *}$, Yonny Koesmaryono ${ }^{1}$, Impron ${ }^{1}$ \\ ${ }^{1}$ Departemen Geofisika dan Meteorologi, Fakultas Matematika dan Ilmu Pengetahuan Alam, \\ Institut Pertanian Bogor, Jalan Miranti Kampus IPB Darmaga, Bogor 16680 \\ ${ }^{2}$ Jurusan Fisika, Fakultas Matematika dan Ilmu Pengetahuan Alam, \\ Universitas Negeri Gorontalo, Jalan Jendral Sudirman No. 6, Gorontalo 96128
}

(diterima Mei 2013, disetujui Juli 2013)

\begin{abstract}
ABSTRAK
Iklim merupakan faktor yang sangat berpengaruh pada kelimpahan hama penggerek batang padi. Penelitian ini bertujuan untuk (i) menyusun model prediksi populasi penggerek batang padi kuning (PBK) dan (ii) menilai kemampuan model untuk memprediksi kelimpahan dan puncak populasi PBK pada skenario perubahan iklim SRES A1FI dan B1. Pemodelan PBK membutuhkan dua komponen utama, yaitu paramater iklim dan suhu ambang bawah perkembangan $\left(\mathrm{T}_{\mathrm{o}}\right)$ untuk menggambarkan siklus hidup PBK dari tahap telur, larva, pupa, dan imago. Penelitian menggunakan perangkat lunak DYMEX yang dapat menggambarkan perkembangan, mortalitas, transfer individu dari satu tahap ke tahap kehidupan selanjutnya, serta fekunditas dan reproduksi PBK. Nilai koefisien determinasi $\left(\mathrm{R}^{2}\right)$ kalibrasi model antara prediksi dan observasi menunjukkan korelasi positif yang kuat dengan nilai $\mathrm{R}^{2}$ sebesar 0,65 . Validasi model juga dapat memprediksi populasi puncak, dengan $\mathrm{R}^{2}$ sebesar 0,42 . Hasil simulasi menunjukkan bahwa kecenderungan puncak populasi terjadi ketika intensitas curah hujan tinggi, yaitu pada bulan Maret sampai April, Juli sampai September, dan November sampai Desember. Model memprediksi populasi PBK di wilayah Sukamandi mencapai 3 generasi per tahun, sedangkan di Kuningan 2 generasi per tahun. Simulasi model di bawah skenario perubahan iklim SRES A1FI dan B1 menunjukkan perbedaan sensitivitas. Ada kecenderungan peningkatan populasi PBK di wilayah Kuningan, dan kecenderungan penurunan di wilayah Sukamandi. Di bawah perubahan iklim, kondisi lingkungan di Kuningan menjadi lebih cocok untuk perkembangbiakan PBK, yang memungkinkan peningkatan jumlah generasi per tahun.
\end{abstract}

Kata kunci: DYMEX, kelimpahan, model populasi, perubahan iklim, puncak populasi

\begin{abstract}
Rice stem borer abundance are largely influenced by climate. This research aims to (i) develop a population dynamic model of yellow stem borer (YSB) and (ii) to assess the model's ability to predict abundance and population peak of YSB under climate change scenario SRES A1FI and B1. Modeling the YSB requires two major components: climate parameter and lower developmental threshold temperatures $\left(T_{0}\right)$ to describe life cycle of YSB from the egg, larva, pupa, and adult stages. The research utilized DYMEX software to describe development, mortality, transfer of individuals from one to the next life stages, fecundity and reproduction of YSB. The coefficient of determination $\left(\mathrm{R}^{2}\right)$ of calibration models between predictions and observations showed a strong positive correlation of 0.65 . Model validation could well predict the peak population, with $\mathrm{R}^{2}=0.42$. The simulations showed that the trend of population peak occur at high rainfall i.e. in March to April, July to

\footnotetext{
*Penulis korespondensi: Syahrizal Koem. Departemen Geofisika dan Meteorologi, Fakultas Matematika dan Ilmu Pengetahuan Alam, Institut Pertanian Bogor, Jalan Miranti Kampus IPB Darmaga, Bogor 16680

Tel: 0251-8623850, Email: syahrizal.koem87@gmail.com
} 


\begin{abstract}
September, and November to December. The model predicted YSB population in the Sukamandi reaches 3 generations per year, while in Kuningan 2 generations per year. Simulation models under climate change scenarios SRES A1FI and B1 showed differences in the sensitivities. Trend of YSB population is increasing in the regions Kuningan and decreasing in region Sukamandi. Under changing climate, environment conditions in Kuningan become more suitable for the proliferation of YSB, allowing an increase in the number of generations per year.
\end{abstract}

Key words: abundance, climate change, DYMEX, population models, population peak

\section{PENDAHULUAN}

Hama penggerek batang padi kuning (PBK) Scirpophaga incertulas (Walker) (Lepidoptera: Crambidae) terdistribusi di wilayah tropis, seperti Bangladesh, India, Malaysia, Pakistan, Filipina, Sri Langka, Thailand, Vietnam, dan sebagian wilayah Indonesia (Pathak \& Khan 1994). Di Indonesia, PBK merupakan hama utama pada tanaman padi dan lebih dominan menyerang khususnya di Provinsi Jawa Barat. Di sisi lain, Jawa Barat merupakan provinsi dengan produksi padi tertinggi, menyumbang rata-rata produksi beras nasional sebesar $17,4 \%$ dengan rata-rata luas panen mencapai 1.967 .781 ha pada tahun 2009 sampai 2012 (BPS 2012). Pada tahun 2012 luas serangan penggerek batang padi di Kabupaten Karawang, Bekasi, Indramayu, dan Subang masing-masing $11.544,10.191,2.377$, dan 1.163 ha (DPTP 2012).

Penyebab munculnya PBK diduga akibat dari perubahan iklim (Estay et al. 2009). Fenomena kemarau panjang yang terjadi pada tahun 1982 sampai 1983 menunjukkan bahwa faktor iklim memicu kematian PBK, sementara kondisi pada saat terjadi kemarau panjang hanya memungkinkan untuk penggerek batang padi putih (PBP) $S$. innotata bertahan hidup, sebab larva PBP mampu berdiapause dan bertahan hidup 10 sampai 12 bulan (Litsinger et al. 2006). Namun, pada tahun 1995 populasi PBP mengalami penurunan, sedangkan populasi PBK meningkat menjadi 30\% sehingga PBK lebih mendominasi dengan populasi lebih dari 90\% (Suharto \& Sembiring 2007; Suharto \& Usyati 2008). Disisi lain, PBK lebih mudah beradaptasi dengan iklim monsun (Litsinger et al. 2006) yang merupakan tipe iklim di wilayah Jawa Barat (Aldrian \& Susanto 2003). Spesies yang mudah beradaptasi cenderung lebih mobile dan lebih cepat bereproduksi (Harrington et al. 2001).

Penyusunan model prediksi dinamika populasi PBK dilakukan untuk keperluan manajemen strategis dan pengambilan keputusan ke depan pada kondisi iklim yang cenderung mengalami perubahan setiap dekade. Berdasarkan laporan IPCC (2007a), sejak tahun 1990 sampai 2005 terjadi peningkatan suhu rata-rata global antara $0,15^{\circ} \mathrm{C}$ sampai $0,30{ }^{\circ} \mathrm{C}$. Dampak perubahan iklim secara langsung akan mempengaruhi dinamika populasi hama pertanian, seperti fisiologi, kelimpahan, fenologi, dan distribusi serangga (Bale et al. 2002; Dukes et al. 2009; Lastuvka 2009; Shi et al. 2011). Selain itu, perubahan iklim mempengaruhi perubahan dimensi hama (Thomson et al. 2010). Beberapa penelitian yang dilakukan menyatakan bahwa perubahan iklim dapat mempengaruhi distribusi serangga fitofag khususnya Lepidoptera yang merupakan ordo dari PBK (Cannon 1998; Parmesan et al. 1999; Batalden et al. 2007; Trnka et al. 2007).

Memahami siklus hidup dan dinamika populasi hama yang erat kaitannya dengan iklim penting dilakukan untuk strategi manajemen jangka panjang (Nylin 2001), sedangkan untuk mengurangi kehilangan hasil produksi dan kerugian ekonomi diperlukan prediksi musiman yang dapat digunakan dalam menerapkan tindakan pengendalian yang efektif (Nahrung et al. 2008). Proses dinamika tersebut dianalisis dengan menggunakan perangkat lunak DYMEX, yang meliputi antara lain perkembangan dan mortalitas, kelimpahan dan waktu puncak populasi PBK pada kondisi iklim yang cenderung fluktuatif. Penelitian ini bertujuan menyusun model prediksi jumlah dan puncak populasi PBK berbasis iklim, dan menguji kemampuan model dalam memprediksi kelimpahan dan puncak populasi PBK pada skenario perubahan iklim SRES A1F1 dan B1.

\section{BAHAN DAN METODE}

Penelitian ini dilaksanakan pada bulan Januari 2013 sampai April 2013 di Laboratorium 
Agrometeorologi, Departemen Geofisika dan Meteorologi, Institut Pertanian Bogor. Penelitian ini terdiri atas pengumpulan data light trap populasi harian imago diperoleh dari Balai Besar Peramalan Organisme Penggangu Tanaman (BBPOPT) Jatisari Kabupaten Karawang pada 5 Juni2011 sampai 10 November 2012, pengumpulan data iklim (suhu minimum dan maksimum, kelembaban minimum dan maksimum, data curah hujan) diperoleh dari dua lokasi stasiun milik Balai Penelitian Agroklimatologi dan Hidrologi (BALITKLIMAT) dan satu stasiun milik BBPOPT Jatisari di wilayah pantai utara Jawa Barat tahun 2009-2012, yaitu Sukamandi Balai Penelitian Tanaman Padi (BALITPA) -6,35 ${ }^{\circ} \mathrm{LS}-107,65^{\circ} \mathrm{BT}$ alt $50 \mathrm{~m}$ dpl, Kuningan Instalasi Penelitian dan Pengkajian Teknologi Pertanian (IPPTP) -6,98 ${ }^{\circ} \mathrm{LS}-108,46{ }^{\circ} \mathrm{BT}$ alt $577 \mathrm{~m}$ dpl, SMPK Jatisari $-6,21{ }^{\circ} \mathrm{LS}-107,30{ }^{\circ} \mathrm{BT}$ alt $28 \mathrm{~m} \mathrm{dpl}$. Penelitian ini menggunakan perangkat lunak DYMEX versi 3.0 untuk menganalisis dinamika populasi PBK dan Climatic Data Generator versi 2.0 untuk membangkitkan data iklim serta Minitab versi 16 untuk uji statistik.

\section{Deskripsi model}

DYMEX merupakan model waktu diskrit yang dapat menelusuri keadaan individu dalam kohort. Sebuah kohort baru akan terbentuk jika satu atau lebih individu memasuki sebuah tahapan kehidupan melalui penggunaan fungsi fisiologis bergantung pada keadaan variabel pada satu waktu tertentu (Kriticos et al. 2009). Pemodelan PBK membutuhkan 2 komponen utama, yaitu paramater iklim dan suhu ambang bawah perkembangan
( $\left.\mathrm{T}_{\mathrm{o}}\right)$ yang dapat diproses dalam siklus hidup menggunakan DYMEX (Gambar 1). Dalam model ini, siklus hidup PBK dapat dimodelkan dari telur, larva, pupa, dan imago. DYMEX mengidentifikasi tahap kehidupan dalam siklus hidup PBK, serangkaian proses yang menggambarkan siklus hidup, perkembangan, mortalitas, transfer individu dari satu tahap ke tahap kehidupan berikutnya, fekunditas dan reproduksi (Nahrung et al. 2008).

\section{Perkembangan dan mortalitas}

Periode perkembangan (hari) yang digunakan untuk menentukan $\mathrm{T}_{\mathrm{o}}$ pada fase telur, larva, dan pupa disajikan pada Tabel 1. $\mathrm{T}_{\mathrm{o}}$ dimaksudkan sebagai suhu ambang yang dapat ditoleransi oleh setiap fase untuk berkembang dan hubungan fungsi linier antara suhu dan laju perkembangan PBK. Data pada Tabel 1 digunakan untuk menentukan laju perkembangan (development rate) pada setiap fase menggukan persamaan $\mathrm{DR}=1 / \mathrm{d}$, dengan DR: laju perkembangan (development rate); d: lama perkembangan (hari) (Lauziere et al. 2002). $\mathrm{T}_{\mathrm{o}}$, yaitu suhu yang menyebabkan tidak terjadi perkembangan PBK atau laju perkembangan $(\mathrm{DR})=0 . \mathrm{T}_{\mathrm{o}}$ setiap fase perkembangan PBK

Tabel 1. Periode perkembangan (hari) telur, larva, dan pupa pada suhu konstan $\left({ }^{\circ} \mathrm{C}\right)$

\begin{tabular}{|c|c|c|c|}
\hline \multirow{2}{*}{ Suhu $\left({ }^{\circ} \mathrm{C}\right)$} & \multicolumn{3}{|c|}{ Periode perkembangan (hari) } \\
\hline & Telur & Larva & Pupa \\
\hline 15 & 24,77 & 75,56 & 15,83 \\
\hline 20 & 10,50 & 55,98 & 12,66 \\
\hline 25 & 9,60 & 22,50 & 9,51 \\
\hline 30 & 5,56 & 15,94 & 5,73 \\
\hline 35 & 2,73 & 15,41 & 4,03 \\
\hline
\end{tabular}

Sumber: (Rahman \& Khalequzzaman 2004).

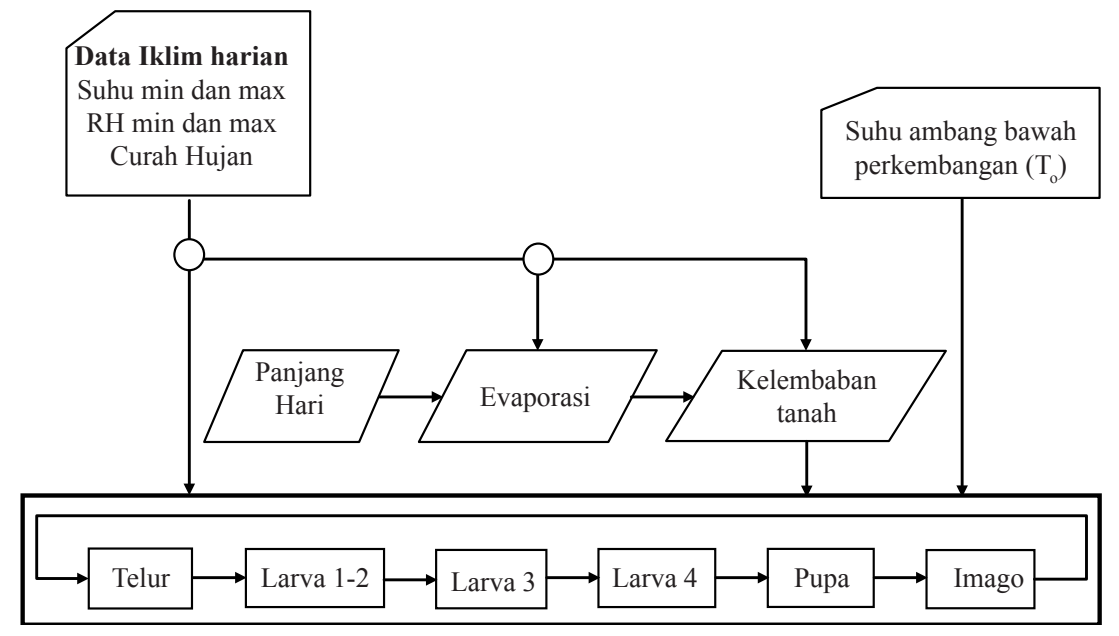

Gambar 1. Skema diagram siklus hidup penggerek batang padi kuning dalam DYMEX. 
ditentukan dengan model regresi linier antara laju perkembangan dan suhu berdasarkan persamaan $\mathrm{y}=\mathrm{a}+\mathrm{b} x$, dengan $\mathrm{y}$ : laju perkembangan $(1 / \mathrm{d}) ;$ $x$ : suhu; a dan b: konstanta (Lauziere et al. 2002; Nahrung et al.2008). $T_{0}$ pada fase imago ditentukan dengan menggunakan persamaan:

$$
\mathrm{DD}=\mathrm{d}\left(\mathrm{T}-\mathrm{T}_{\mathrm{o}}\right) \text {, dengan }
$$

d: lama perkembangan (hari); T: suhu tinggi yang dibutuhkan untuk perkembangan $\left({ }^{\circ} \mathrm{C}\right) ; \mathrm{T}_{\mathrm{o}}$ : suhu dasar $\left({ }^{\circ} \mathrm{C}\right)$; DD: derajat hari (Lauziere et al. 2002).

Mortalitas dalam model ini didorong oleh suhu dan kelembaban tanah. Mortalitas konstan pada fase larva diasumsikan 0,01 per hari, sedangkan mortalitas imago dimodelkan dengan menggunakan nilai 0,1 sehingga mengurangi jumlah populasi sebesar 10\% (Maywald et al. 2007b). Mortalitas diasumsikan terkait dengan musuh alami, faktor biotik dan abiotik, serta mortalitas akibat usia. Selain itu, larva terlindungi dari faktor-faktor yang menyebabkan mortalitas, sebab posisi larva berada di dalam batang padi. Hal ini yang menyebabkan mortalitas larva relatif lebih rendah dari mortalitas imago.

\section{Tahapan transfer (stage transfer)}

Seluruh fase mentransfer setelah mencapai perkembangan penuh, yaitu mencapai usia fisiologis 1. Jika ambang usia fisiologis diatur ke nilai 1 maka usia fisiologis pada setiap waktu akan sama, seperti akumulasi derajat hari di atas ambang suhu perkembangan (Yonow et al. 2004; Maywald et al. 2007a; Nahrung et al. 2008).

\section{Fekunditas dan reproduksi}

Fekunditas secara umum diartikan sebagai kemampuan serangga untuk bereproduksi, dan dimodelkan dalam bentuk parameter potensial telur PBK. Jika setiap betina PBK mampu memproduksi telur sebanyak 100 sampai 600 butir (Suharto \& Usyati 2008) dan usia rata-rata jantan dan betina masing-masing 2,5 dan 5,09 hari (Krishnaiah et al. 2004), serta dengan mengasumsikan bahwa sex ratio antara jantan dan betina adalah $1: 2$ maka diperoleh telur sebanyak 400 butir dalam populasi.

Reproduksi diasumsikan dikendalikan oleh siklus suhu harian dan curah hujan. Produksi meningkat jika siklus suhu harian berkisar $22{ }^{\circ} \mathrm{C}$, hal ini didasarkan pada suhu minimum ratarata wilayah kajian. Penggunaan suhu minimum sebagai indikator reproduksi disebabkan oleh imago betina bereproduksi dan meletakkan telur pada malam hari (bersifat nokturnal). Oleh karena itu, suhu minimum rata-rata dinilai cukup tepat untuk digunakan, sedangkan curah hujan 5 sampai $40 \mathrm{~mm}$ atau lebih digunakan sebagai nilai acuan puncak aktivitas munculnya imago betina untuk bereproduksi (Yonow et al. 2004; Krishnaiah et al. 2004).

\section{Kalibrasi, validasi, dan simulasi model}

Kalibrasi dan validasi model dilakukan di wilayah Jatisari Kabupaten Karawang menggunakan data populasi imago yang tersedia di lapangan sejak 5 Juni 2011 sampai 10 November 2012, kemudian dibandingkan dengan jumlah populasi yang diperoleh dari hasil prediksi model. Evaluasi kebaikan model mengacu pada indeks statistik koefisien determinasi $\left(\mathrm{R}^{2}\right)$ antara 0 sampai 1. Simulasi model menggunakan data iklim harian tanggal 1 April 2009 sampai 31 Oktober 2012 untuk menganalisis pola dinamika populasi PBK.

\section{Skenario perubahan iklim}

Nilai perubahan iklim digunakan untuk melihat respon $\mathrm{PBK} \pm 60$ tahun kedepan (Tabel 2). Skenario dan proyeksi perubahan suhu udara dan curah hujan berdasarkan pada laporan special report on emissions scenarios (SRES) A1FI dan B1, yaitu proyeksi tahun 2020-an dan 2050-an dengan sub wilayah Southeast Asia (10S - 12N; 100E - 150E) (IPCC 2007b). Respon perbedaan populasi pada setiap skenario perubahan iklim terhadap kondisi iklim kini dianalisis menggunakan uji t untuk 2 sampel berpasangan (paired two sample for means).

\section{HASIL}

\section{Persyaratan ambang suhu perkembangan PBK}

Penentuan $T_{0}$ PBK menggunakan model regresi linier yang didukung oleh data periode perkembangan setiap fase PBK sehingga diperoleh laju perkembangan (1/d) untuk telur 0,040, 0,095, $0,104,0,180,0,366$, sedangkan laju perkembangan larva $0,013,0,018,0,044,0,063,0,065$, dan laju perkembangan pupa $0,063,0,079,0,105,0,175$, 0,248 pada suhu 15 sampai $35{ }^{\circ} \mathrm{C}$. Nilai laju perkembangan setiap fase kemudian digunakan 
untuk menentukan $\mathrm{T}_{\mathrm{o}}$ dimana tidak terjadi perkembangan pada setiap fase PBK sehingga diperoleh $\mathrm{T}_{\mathrm{o}}$ adalah $14,4{ }^{\circ} \mathrm{C}, 11,2^{\circ} \mathrm{C}$, dan $10,6^{\circ} \mathrm{C}$ untuk telur, larva, dan pupa pada suhu 15 sampai $35{ }^{\circ} \mathrm{C}$ (Tabel 3) sedangkan untuk menentukan $\mathrm{T}_{\mathrm{o}}$ pada fase imago menggunakan nilai thermal constant (DD) dan usia rata-rata (hari) yang dilaporkan oleh Rahman \& Khalequzzaman (2004), yaitu 75,2 DD dan 4,8 hari sehingga diperoleh nilai $\mathrm{T}_{\mathrm{o}}$ untuk fase imago, yaitu $19,2{ }^{\circ} \mathrm{C}$.

\section{Kalibrasi dan validasi model}

Luaran hasil prediksi model jumlah populasi imago PBK dan jumlah populasi tangkapan light trap harian dikonversi menjadi total populasi 3 minggu. Luaran hasil prediksi model dan observasi menggunakan nilai $\ln x+1$ untuk memperkecil nilai karena perbedaan nilai sangat besar antara hasil prediksi model dan observasi. Hasil uji statistik menunjukkan bahwa terdapat perbedaan antara hasil prediksi dan observasi, yaitu jumlah populasi hasil prediksi lebih tinggi dari jumlah populasi observasi. Namun, prediksi model cenderung mengikuti pola fluktuasi observasi (Gambar 2b) sehingga dapat dikatakan bahwa model yang dibangun hanya memprediksi puncak kelimpahan populasi dan tidak memprediksi secara spesifik jumlah populasi. Nilai $\mathrm{R}^{2}$ antara prediksi dan observasi menunjukkan hubungan yang kuat dan berkorelasi positif dengan nilai $\mathrm{R}^{2}$ sebesar 0,65 (Gambar 2a).
Proses validasi model menunjukkan hasil yang baik antara hasil prediksi dan observasi periode terjadinya puncak populasi. Model dengan baik memprediksi puncak kelimpahan populasi selama periode simulasi. Namun, pada beberapa titik prediksi puncak kelimpahan populasi bergeser 30 hari dari observasi (Gambar 3b). Hubungan linier antara observasi dan prediksi dengan nilai $\mathrm{R}^{2}$ sebesar 0,42 (Gambar 3a). Meskipun nilai $\mathrm{R}^{2}$ hasil kalibrasi dan validasi berbeda, namun hasil validasi model dengan nilai $\mathrm{R}^{2}$ sebesar 0,42 memberikan gambaran bahwa $42 \%$ dinamika populasi PBK dipengaruhi oleh faktor iklim, sedangkan 58\% dinamika populasi PBK dipengaruhi oleh faktor lain.

\section{DYMEX: Simulasi model pada kondisi iklim kini dan skenario perubahan iklim}

Simulasi pada kondisi iklim kini di wilayah Sukamandi menunjukan kecenderungan puncak populasi terjadi ketika curah hujan tinggi, yaitu pada bulan Maret sampai April, Juli sampai September, dan bulan November sampai Desember. Populasi PBK pada semua fase pada saat curah hujan tinggi menunjukan jumlah populasi PBK rendah, sedangkan ketika curah hujan rendah populasi PBK tinggi (Gambar 4). Hasil prediksi model menunjukan bahwa populasi PBK mencapai 3 generasi per tahun di wilayah Sukamandi (Gambar 4), sedangkan di Kuningan 2 generasi per tahun (Gambar 5), hal ini disebabkan

Tabel 2. Nilai yang digunakan dalam simulasi untuk skenario perubahan iklim tahun 2020-an dan 2050-an

\begin{tabular}{|c|c|c|c|c|c|c|c|c|c|}
\hline \multirow{3}{*}{ Sub-wilayah } & \multirow{3}{*}{ Bulan } & \multicolumn{4}{|c|}{ 2020-an } & \multicolumn{4}{|c|}{ 2050-an } \\
\hline & & \multicolumn{2}{|c|}{ Suhu $\left({ }^{\circ} \mathrm{C}\right)$} & \multicolumn{2}{|c|}{$\mathrm{CH}(\%)$} & \multicolumn{2}{|c|}{ Suhu $\left({ }^{\circ} \mathrm{C}\right)$} & \multicolumn{2}{|c|}{$\mathrm{CH}(\%)$} \\
\hline & & $\mathrm{A}_{1 F I^{\mathrm{a}}}$ & $\mathrm{B} 1^{\mathrm{b}}$ & A1FI $^{\mathrm{a}}$ & $\mathrm{B} 1^{\mathrm{b}}$ & $\mathrm{A}_{1 F I^{\mathrm{a}}}$ & $\mathrm{B} 1^{\mathrm{b}}$ & $\mathrm{A} 1 \mathrm{FI}^{\mathrm{a}}$ & $\mathrm{B} 1^{\mathrm{b}}$ \\
\hline \multirow{4}{*}{$\begin{array}{l}\text { Southeast Asia } \\
(10 \mathrm{~S}-12 \mathrm{~N} ; 100 \mathrm{E}- \\
150 \mathrm{E})\end{array}$} & DJF & 0,86 & 0,72 & -1 & 1 & 2,25 & 1,32 & 2 & 4 \\
\hline & MAM & 0,92 & 0,80 & 0 & 0 & 2,32 & 1,34 & 3 & 3 \\
\hline & JJA & 0,83 & 0,74 & -1 & 0 & 2,13 & 1,30 & 0 & 1 \\
\hline & SON & 0,85 & 0,75 & -2 & 0 & 1,32 & 1,32 & -1 & 1 \\
\hline
\end{tabular}

Sumber: IPCC (2007b); CH: curah hujan; ${ }^{a} \mathrm{~A} 1 \mathrm{FI}$ : emisi tinggi; ${ }^{\mathrm{b}} \mathrm{B} 1$ : emisi rendah.

Tabel 3. Persamaan regresi, $\mathrm{R}^{2}$, suhu ambang bawah perkembangan $\left(\mathrm{T}_{\mathrm{o}}\right)$ dan derajat hari untuk perkembangan telur, larva, dan pupa penggerek batang padi kuning

\begin{tabular}{|c|c|c|c|c|}
\hline Fase perkembangan & Persamaan regresi $^{a}$ & $\mathrm{R}^{2}$ & $\mathrm{~T}_{\mathrm{o}}\left({ }^{\circ} \mathrm{C}\right)^{\mathrm{b}}$ & DD \\
\hline Telur & $y=0,0147 x-0,2111$ & 0,84 & 14,4 & 55,61 \\
\hline Larva & $y=0,003 x-0,0335$ & 0,93 & 11,2 & 367,22 \\
\hline Pupa & $y=0,0093 x-0,0987$ & 0,92 & 10,6 & 98,29 \\
\hline
\end{tabular}

a Rentang suhu $15-35^{\circ} \mathrm{C}$; Model regresi linier $\mathrm{y}=\mathrm{a}+\mathrm{bx}$, dengan y adalah laju perkembangan (1/hari), $\mathrm{x}$ adalah suhu, a dan $\mathrm{b}$ dalah konstanta.

${ }^{\mathrm{b}} \mathrm{T}_{\mathrm{o}}$ : suhu ambang bawah perkembangan; DD: degree days; $\mathrm{R}^{2}$ : nilai koefisien determinasi. 
(a)

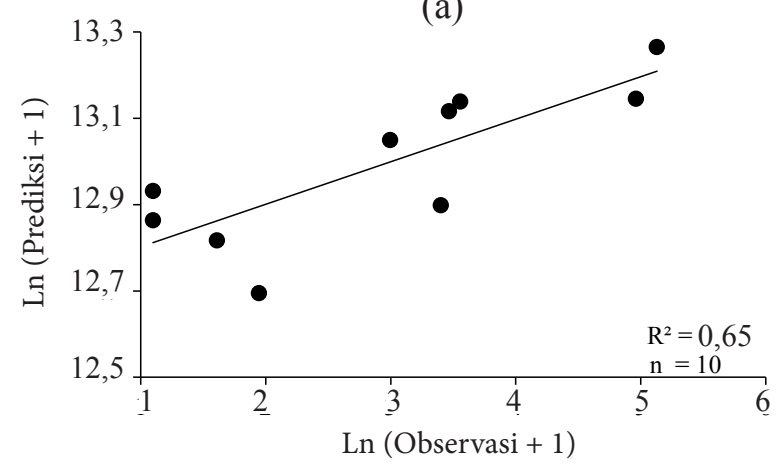

(b)

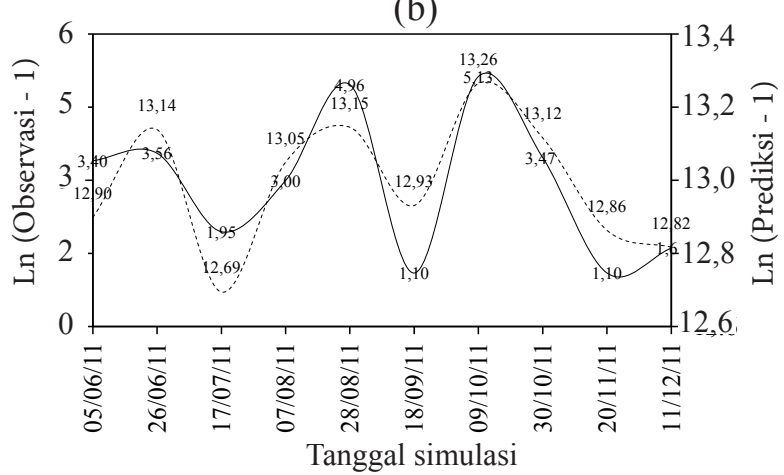

Gambar 2. (a) Hubungan antara jumlah populasi imago penggerek batang padi kuning hasil prediksi dan observasi hasil kalibrasi. (b) Jumlah populasi imago 3 minggu 5 Juni-31 Deseber 2011, hasil prediksi (- - ) dan observasi (-) penggerek batang padi kuning.

(a)

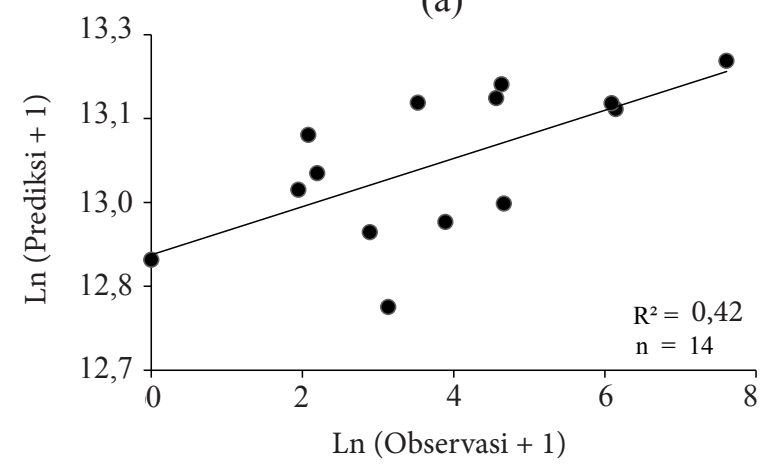

(b)

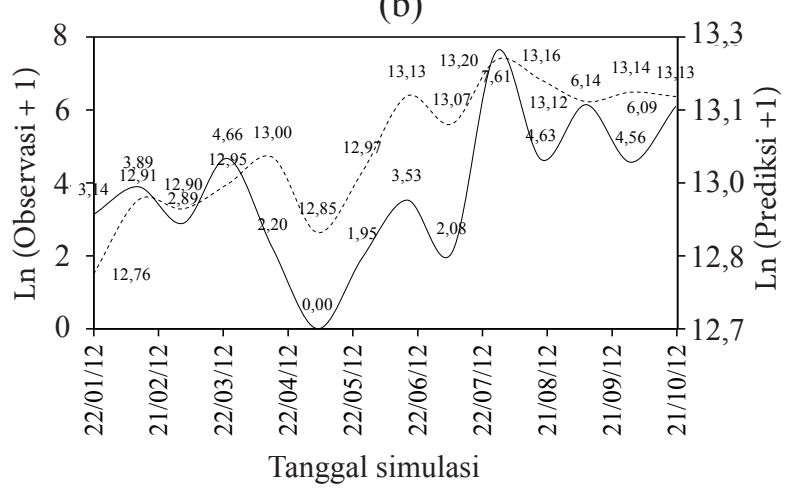

Gambar 3. (a) Hubungan antara jumlah populasi imago penggerek batang padi kuning hasil prediksi dan observasi hasil validasi. (b) Jumlah populasi imago penggerek batang padi kuning 3 minggu 22 Januari-10 November 2012, hasil prediksi (- - -) dan observasi (-) penggerek batang padi kuning.

oleh pengaruh faktor iklim, yaitu suhu terhadap dinamika yang diterapkan dalam model.

Simulasi model pada skenario perubahan iklim A1FI dan B1 di wilayah Sukamandi menunjukkan adanya perbedaan yang signifikan jumlah populasi imago setelah dilakukan skenario, dengan kecenderungan penurunan jumlah populasi imago untuk proyeksi tahun 2020-an dan 2050-an (Tabel 4 dan 5). Sedangkan jumlah populasi telur pada kondisi iklim kini menunjukkan adanya jumlah populasi yang sama pada saat dilakukan skenario, dengan kata lain telur masih dapat mentolerir peningkatan suhu pada tahun 2020-an dan 2050-an.

Simulasi model di wilayah Kuningan pada ketinggian $577 \mathrm{~m}$ dpl memperlihatkan sensitivitas model terhadap dampak perubahan iklim pada dinamika jumlah populasi PBK (Gambar 5). Hasil simulasi diperoleh bahwa pada 2 skenario perubahan iklim yang dilakukan terjadi perbedaan dinamika jumlah populasi PBK. Hasil uji statistik menunjukkan adanya perbedaan jumlah populasi pada kondisi iklim kini dengan jumlah populasi pada 2 skenario perubahan iklim, dengan kecenderungan kenaikan jumlah populasi PBK (Tabel 4 dan 5).

\section{PEMBAHASAN}

Penurunan jumlah populasi PBK pada kondisi iklim kini di wilayah Kuningan dapat disebabkan oleh penurunan fekunditas akibat penurunan suhu (Hodkinson 2005). Penurunan suhu disebabkan oleh perbedaan ketinggian, dimana wilayah Kuningan memiliki ketinggian lebih tinggi (577 m dpl) bila dibandingkan dengan wilayah Sukamandi $(50 \mathrm{~m} \mathrm{dpl})$. Hal ini didukung oleh beberapa penelitian sebelumnya yang menyatakan bahwa jumlah spesies serangga menurun dengan meningkatnya lintang (Wilf \& Labandeira 1999), hal serupa ditemukan bahwa dengan meningkatnya ketinggian terjadi penurunan jumlah spesies yang 

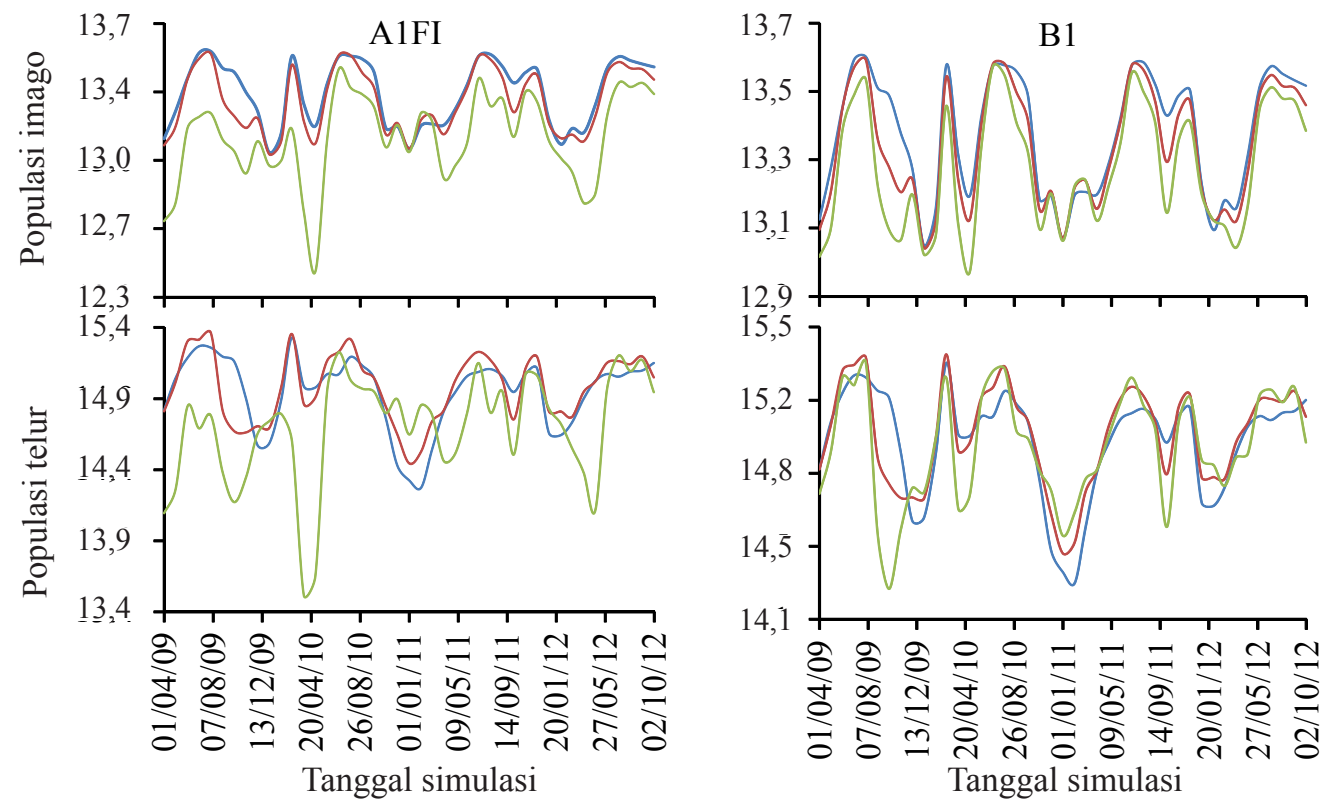

Gambar 4. Dinamika populasi penggerek batang padi kuning pada skenario perubahan iklim SRES A1FI dan B1 untuk imago dan telur wilayah Sukamandi. (-) kini, (-) 2020-an, (-) 2050-an.
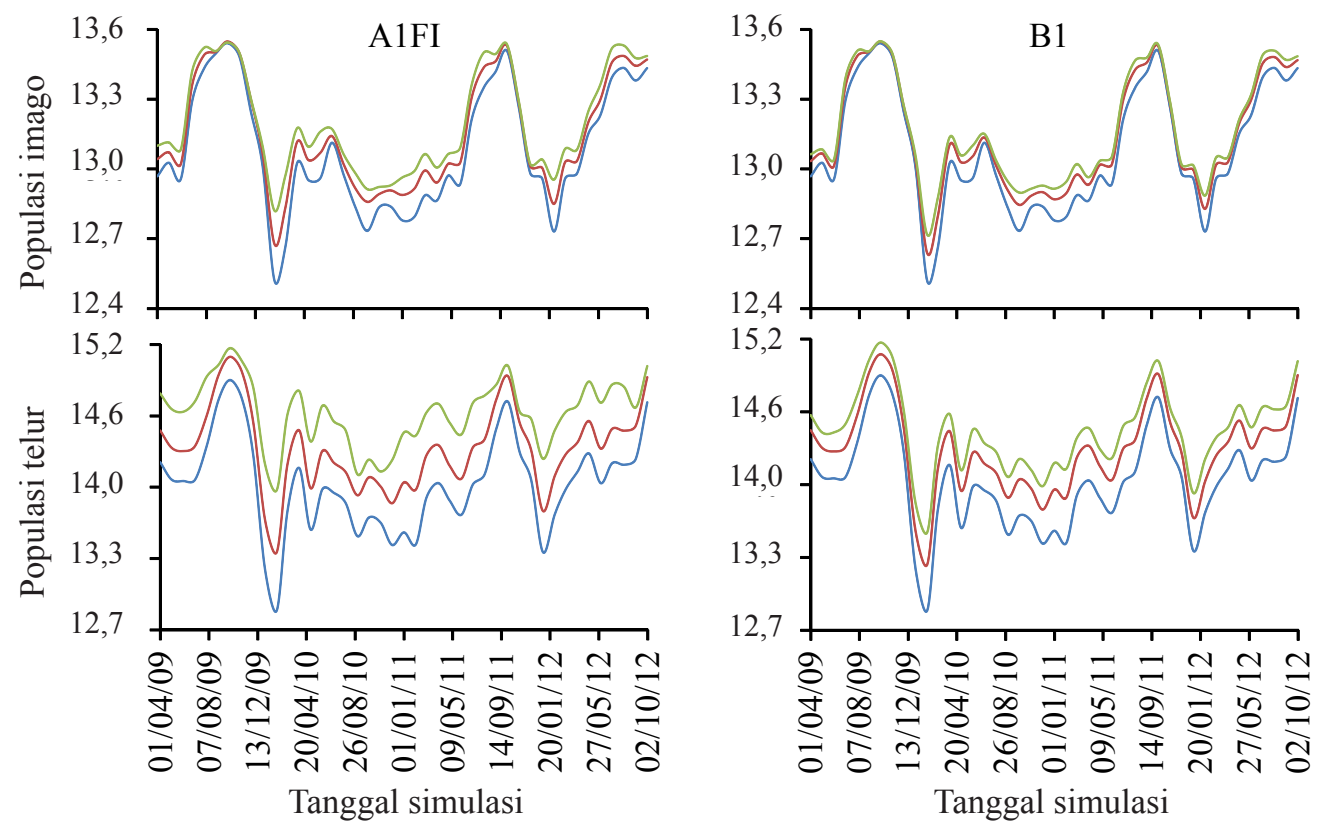

Gambar 5. Dinamika populasi penggerek batang padi kuning pada skenario perubahan iklim SRES A1FI dan B1 untuk imago dan telur wilayah Kuningan. (-) kini, (-) 2020-an, (-) 2050-an.

disebabkan oleh pengaruh lingkungan (Hoiss et al. 2012). Selain itu, tempat yang lebih tinggi dapat memperlambat reproduksi serangga (Duyck et al. 2010) sehingga jumlah generasi dan jumlah populasi serangga cenderung lebih sedikit.

Kenaikan jumlah populasi PBK di wilayah Kuningan disebabkan oleh semua fase PBK mencapai kondisi suhu ideal untuk berkembang. Pada dasarnya, wilayah Kuningan terletak pada tempat yang lebih tinggi sehingga pada kondisi iklim kini jumlah populasi di wilayah Kuningan lebih rendah dibandingkan dengan jumlah populasi di wilayah Sukamandi.

Laju perkembangan (development rate) merupakan suatu variabel mendasar dalam membangun model fenologi PBK yang digunakan untuk menentukan $\mathrm{T}_{\mathrm{o}}$ sehingga dengan adanya $\mathrm{T}_{\mathrm{o}}$ dapat digunakan untuk memprediksi puncak populasi di setiap wilayah. Karitani (2006); Nietschke et al. (2007) menyatakan bahwa penggunaan $\mathrm{T}_{\mathrm{o}}$ dan thermal constant $(\mathrm{K})$ berguna dalam menyusun model fenologi populasi serangga 
Tabel 4. Dinamika populasi penggerek batang padi kuning wilayah Sukamandi dan Kuningan di bawah skenario perubahan iklim SRES A1FI

\begin{tabular}{|c|c|c|c|c|c|c|c|}
\hline \multirow[b]{2}{*}{ Wilayah } & \multirow{2}{*}{ Fase perkembangan } & \multicolumn{3}{|c|}{ 2020-an } & \multicolumn{3}{|c|}{ 2050-an } \\
\hline & & $\mathrm{t}_{\text {value }}$ & $\mathrm{P}_{\text {value }}{ }^{\mathrm{a}}$ & $\mathrm{S} / \mathrm{TS}$ & $\mathrm{t}_{\text {value }}$ & $\mathrm{P}_{\text {value }}{ }^{\mathrm{a}}$ & $\mathrm{S} / \mathrm{TS}$ \\
\hline \multirow[t]{4}{*}{ Sukamandi } & Imago & 5,29 & 0,000 & $\mathrm{~S}$ & 10,57 & 0,000 & $\mathrm{~S}$ \\
\hline & Telur & $-1,52$ & 0,136 & TS & 4,01 & 0,000 & $\mathrm{~S}$ \\
\hline & Larva & $-0,57$ & 0,574 & TS & 1,32 & 0,194 & TS \\
\hline & Pupa & $-1,00$ & 0,323 & TS & 1,32 & 0,195 & TS \\
\hline \multirow[t]{4}{*}{ Kuningan } & Imago & $-15,50$ & 0,000 & $\mathrm{~S}$ & $-13,76$ & 0,000 & $\mathrm{~S}$ \\
\hline & Telur & $-28,17$ & 0,000 & $\mathrm{~S}$ & $-28,81$ & 0,000 & $\mathrm{~S}$ \\
\hline & Larva & $-8,29$ & 0,000 & $\mathrm{~S}$ & $-8,33$ & 0,000 & $\mathrm{~S}$ \\
\hline & Pupa & $-9,14$ & 0,000 & $\mathrm{~S}$ & $-8,88$ & 0,000 & $\mathrm{~S}$ \\
\hline
\end{tabular}

${ }^{a}$ Taraf nyata sebesar 5\%; S: signifikan; TS: tidak signifikan.

Tabel 5. Dinamika populasi penggerek batang padi kuning wilayah Sukamandi dan Kuningan di bawah skenario perubahan iklim SRES B1

\begin{tabular}{|c|c|c|c|c|c|c|c|}
\hline \multirow{2}{*}{ Wilayah } & \multirow[b]{2}{*}{ Fase perkembangan } & \multicolumn{3}{|c|}{ 2020-an } & \multicolumn{3}{|c|}{ 2050-an } \\
\hline & & $\mathrm{t}_{\text {value }}$ & $\mathrm{P}_{\text {value }}{ }^{\mathrm{a}}$ & $\mathrm{S} / \mathrm{TS}$ & $\mathrm{t}_{\text {value }}$ & $\mathrm{P}_{\text {value }}{ }^{\mathrm{a}}$ & $\mathrm{S} / \mathrm{TS}$ \\
\hline \multirow{4}{*}{ Sukamandi } & Imago & 5,08 & 0,000 & $\mathrm{~S}$ & 7,54 & 0,000 & $\mathrm{~S}$ \\
\hline & Telur & $-1,81$ & 0,078 & TS & 0,50 & 0,622 & TS \\
\hline & Larva & $-0,63$ & 0,532 & TS & 0,19 & 0,846 & TS \\
\hline & Pupa & $-0,87$ & 0,388 & TS & 0,27 & 0,788 & TS \\
\hline \multirow[t]{4}{*}{ Kuningan } & Imago & $-15,09$ & 0,000 & $\mathrm{~S}$ & $-14,31$ & 0,000 & $\mathrm{~S}$ \\
\hline & Telur & $-24,99$ & 0,000 & $\mathrm{~S}$ & $-28,19$ & 0,000 & $\mathrm{~S}$ \\
\hline & Larva & $-8,47$ & 0,000 & $\mathrm{~S}$ & $-8,58$ & 0,000 & $\mathrm{~S}$ \\
\hline & Pupa & $-9,14$ & 0,000 & $\mathrm{~S}$ & $-9,11$ & 0,000 & $\mathrm{~S}$ \\
\hline
\end{tabular}

${ }^{a}$ Taraf nyata sebesar 5\%; S: signifikan; TS: tidak signifikan.

di era pemanasan global karena fenologi serangga bergantung pada suhu yang memungkinkan terjadinya distribusi geografis serangga (Regniere et al. 2012).

Agar aktivitas memprediksi kejadian hama dapat dilakukan secara lebih baik diperlukan adanya sebuah database dari faktor yang relevan yang mempengaruhi terjadinya kelimpahan hama (Nietschke et al. 2007; Yang et al. 2009), salah satu yang utama adalah database suhu ambang bawah perkembangan $\left(\mathrm{T}_{\mathrm{o}}\right)$. Memproyeksikan risiko spesies serangga di bawah skenario perubahan iklim membutuhkan pengamatan time series sejarah dan translokasi spesies untuk validasi (Sutherst et al. 2007). Sebuah kerangka prediksi lebih bermanfaat jika pengembangan model didasarkan pada pemahaman terhadap proses fenologi serangga yang akan dimodelkan, terutama serangga dan tanaman inangnya (Thomson et al. 2010). Kompleksitas faktor ini tidak menjadi hambatan dalam membangun model fenologi populasi karena pemodelan fenologi menggunakan DYMEX memberikan pilihan komponen dalam menjalankan proses simulasi dengan sederhana yang telah disediakan dalam perpustakaan modul sesuai dengan serangga yang akan dimodelkan dan faktor-faktor yang mempengaruhi kelimpahannya. Namun, pemodelan yang hanya memperhatikan fakor iklim memberikan pengaruh yang cukup besar terhadap dinamika populasi serangga. Yonow et al. (2004) menyatakan bahwa 37\% faktor iklim mempengaruhi dinamika serangga dinilai hasil prediksi model cukup baik.

\section{KESIMPULAN}

Model mampu memprediksi dengan baik pengaruh iklim terhadap populasi PBK dan menghasilkan pola tren yang sesuai antara hasil prediksi dan observasi. Model memprediksi dengan baik jumlah generasi dan puncak populasi ketika intensitas curah hujan tinggi maupun intensitas curah hujan rendah. Puncak populasi tertinggi terjadi pada saat intensitas curah hujan rendah. Model juga dapat diterapkan pada 
kondisi perubahan iklim sehingga membantu memberikan informasi untuk menilai tingkat risiko dampak perbahan iklim terhadap tingkat kelimpahan populasi PBK. Kemampuan model DYMEX tersebut dapat dipakai untuk merumuskan manajemen dan perencanaan pengendalian populasi PBK saat ini dan masa depan.

\section{UCAPAN TERIMA KASIH}

Ucapan terima kasih kepada Lilik Retnowati dan Davied Aprianto Sofyan dari BBPOPT atas dukungan data light trap imago dan data iklim. Terima kasih juga penulis sampaikan kepada Karmila Sari dari BALITKLIMAT atas dukungan data iklim dan kepada jajaran Direktorat Perlindungan Tanaman Pangan RI atas dukungan data serangan penggerek batang padi.

\section{DAFTAR PUSTAKA}

Aldrian E, Susanto RD. 2003. Identification of three dominant rainfall regions within indonesia and their relationship to sea surface temperature. International Journal of Climatologi 23:14351452. doi: http://dx.doi.org/10.1002/joc.950.

Bale JS, Masters GJ, Hodkinson ID, Awmack C, Bezemer TM, Brown VK, Butterfield J, Buse A, Coulson JC et al. 2002. Herbivory in global climate change research: direct effects of rising temperatures on insect herbivores. Global Change Biology 8:1-16. doi: http://dx.doi. org/10.1046/j.1365-2486.2002.00451.x.

Batalden RV, Oberhauser K, Peterson AA. 2007. Ecological niches in sequential generations of eastern North American Monarch butterflies (Lepidoptera: Danaidae): the ecology of migration and likely climate change implications. Environmental Entomology 36:1365-1373. doi: http://dx.doi.org/10.1603/0046-225X(2007)36[1 365:ENISGO]2.0.CO;2.

[BPS] Badan Pusat Statistik. 2012. Statistik Indonesia 2012. Jakarta: Badan Pusat Statistik.

Cannon RJC. 1998. The implications of predicted climate change for insect pests in the UK, with emphasis on non-indigenous species. Global Change Biology 4:785-796. doi: http://dx.doi. org/10.1046/j.1365-2486.1998.00190.x.

[DPTP] Direktorat Perlindungan Tanaman Pangan. 2012. Data Luas Serangan Penggerek Batang Padi 2005-2012. Jakarta: DPTP

Dukes JS, Pontius J, Orwig D, Garnas JR, Rodgers VL, Brazee N, Cooke B, Theoharides KA, Stange
EE, Harrington R et al. 2009. Responses of insect pests, pathogens, and invasive plant species to climate change in the forests of northeastern North America: What can we predict?. Canadian Journal of Forest Research 39:231-248. doi: http://dx.doi.org/10.1139/X08-171.

Duyck PF, Kouloussis NA, Papadopoulos NT, Quilici S, Wang JL, Jiang CR, Muller HG, Carey JR. 2010. Lifespan of a Ceratitis fruit fly increases with higher altitude. Biological Journal of the Linnean Society 101:345-350. doi: http://dx.doi. org/10.1111/j.1095-8312.2010.01497.x.

Estay SA, Lima M, Labra FA. 2009. Predicting insect pest status under climate change scenarios: combining experimental data and population dynamics modelling. Journal of Applied Entomology 133:491-499. doi: http://dx.doi. org/10.1111/j.1439-0418.2008.01380.x.

Harrington R, Fleming RA, Woiwod IP. 2001. Climate change impacts on insect management and conservation in temperate regions: can they be predicted?. Agricultural and Forest Entomology 3:233-240. doi: http://dx.doi.org/10.1046/j.14619555.2001.00120.x.

Hodkinson ID. 2005. Terrestrial insects along elevation gradients: species and community responses to altitude. Biology Review 80:489-513. doi: http:// dx.doi.org/10.1017/S1464793105006767.

Hoiss B, Krauss J, Potts SG, Roberts S, Dewenter IS. 2012. Altitude acts as an environmental filter on phylogenetic composition, traits and diversity in bee communities. Proceedings of the Royal Society B. 279:4447-4456. doi: http://dx.doi. org/10.1098/rspb.2012.1581.

[IPCC] Intergovernmental Panel on Climate Change. 2007a. Summary for policymakers: A report of working group I. Cambridge and New York: Cambridge University Press.

[IPCC] Intergovernmental Panel on Climate Change. 2007b. Impacts, adaptation and vulnerability. Contribution of Working Group II. Cambridgeand New York: Cambridge University Press.

Kiritani K. 2006. Predicting impacts of global warming on population dynamics and distribution of arthropods in Japan. Review. Population Ecology 48:5-12. doi: http://dx.doi.org/10.1007/ s10144-005-0225-0.

Krishnaiah NV, Prasad ASR, Reddy CS, Pasalu IC, Mishra B, Krishna YSR, Prasad YG, Prabhakar M. 2004. Forewarning and management of rice yellow stem borer Scirpophaga incertulas (Walker). Directorate of Rice Research Rajendranagar. Technical Bulletin 7:1-39.

Kriticos DJ, Watt MS, Withers TM, Leriche A, Watson MC. 2009. A process-based population dynamics model to explore target and non-target impacts of 
a biological control agent. Ecological Modelling 220:2035-2050. doi: http://dx.doi.org/10.1016/j. ecolmodel.2009.04.039.

Lastuvka Z. 2009. Climate change and its possible influence on the occurrence and importance of insect pests. Plant Protection Science 45:S53-S62.

Lauziere I, Setamou M, Legaspi J, Jones W. 2002. Effect of temperature on life cycle of Lydella jalisco (Diptera: Tachinidae), a parasitoid of Eoreuma loftini (Lepidoptera: Pyralidae). Environmental Entomology 31:432-437. doi: http://dx.doi.org/10.1603/0046-225X-31.3.432.

Litsinger JA, Alviola AL, Cruz CGD, Canapi BL, Batay-An EH, Barrion AT. 2006. Rice white stemborer Scirpophaga incertulas (Walker) in Southern Mindanao, Philippines. I. supplantation of yellow stemborer $S$. incertulas (Walker) and pest status. International Journal of Pest Management 52:11-21. doi: http://dx.doi. org/10.1080/09670870600552497.

Maywald GF, Kriticos DJ, Sutherst RW, Bottomley W. 2007a. DYMEX model builder version 3. Melbourne: CSIRO Publising.

Maywald GF, Bottomley W, Sutherst RW. 2007b. DYMEX model simulator version 3. Melbourne: CSIRO Publising.

Nahrung HF, Schutze MK, Clarke AR, Duffy MP, Dunlop EA, Lawson SA. 2008. Thermal requirements, field mortality and population phenology modelling of Paropsis atomaria Olivier, an emergent pest in subtropical hardwood plantations. Forest Ecology and Management 255:3515-3523. doi: http://dx.doi.org/10.1016/j. foreco.2008.02.033.

Nietschke BS, Magarey RD, Borchert DM, Calvin DD, Jones E. 2007. A developmental database to support insect phenology models. Crop Protection 26:1444-1448. doi: http://dx.doi. org/10.1016/j.cropro.2006.12.006.

Nylin S. 2001. Life history perspectives on pest insects: What's the use? Australian of Ecology 26:507-517. doi: http://dx.doi.org/10.1046/j.1442 -9993.2001.01134.x.

Parmesan C, Ryrholm N, Stefanescus C, Hill JK, Thomas CD, Descimon H, Huntley B, Kaila L, Kullberg J, Tammaru T, Tennent WJ, Thomas JA, Warren M. 1999. Poleward shifts in geographical ranges of butterfly species associated with regional warming. Nature 399:579-583. doi: http://dx.doi.org/10.1038/21181.

Pathak MD, Khan ZR. 1994. Insect Pest of Rice. Manila: International Rice Research Institute.

Rahman MT, Khalequzzaman. 2004. Temperature requirements for the development and survival of rice stemborers in laboratory conditions. Entomologia Sinica 11:47-60.
Regniere J, Powell J, Bentz B, Nealis V. 2012. Effects of temperature on development, survival and reproduction of insects: experimental design, data analysis and modeling. Journal of Insect Physiology 58:634-647. doi: http://dx.doi. org/10.1016/j.jinsphys.2012.01.010.

Shi P, Zhong L, Sandhu HS, Ge F, Xu X, Chen W. 2011. Population decrease of Scirpophaga incertulas (Walker) (Lepidoptera Pyralidae) under climate warming. Ecologi and Evolution 2:58-64. doi: http://dx.doi.org/10.1002/ece3.69.

Suharto H, Sembiring H. 2007. Status hama penggerek batang padi di Indonesia: Apresiasi hasil penelitian padi. BPTP 61-71.

Suharto H, Usyati N. 2008. Pengendalian hama penggerek batang padi. Di dalam: Daradjat et al. (Eds.). Padi Inovasi Teknologi Produksi. pp. 327-349. Balai Besar Penelitian Tanaman Padi. Jakarta. LIPI Press.

Sutherst RW, Maywald GF, Bourne S. 2007. Including species interactions in risk assessments for global change. Global Change Biology 13:1843-1859. doi: http://dx.doi.org/10.1111/j.1365-2486.2007. 01396.x.

Thomson LJ, Macfadyen S, Hoffmann AA. 2010. Predicting the effects of climate change on natural enemies of agricultural pests. Biological Control 52:296-306. http://dx.doi.org/10.1016/j. biocontrol.2009.01.022.

Trnka M, Muskab F, Semeradovaa D, Dubrovsky M, Kocmankovaa E, Zaluda Z. 2007. European corn borer life stage model: regional estimates of pest development and spatial distribution under present and future climate. Ecological Modelling 207:61-84. doi: http://dx.doi.org/10.1016/j.ecol model.2007.04.014.

Wilf P, Labandeira CC. 1999. Response of plantinsect associations to paleocene-eocene warming. Science 284:2153-2156. doi: http://dx.doi.org/ 10.1126/science.284.5423.2153.

Yang LN, Peng L, Zhang LM, Zhang LL, Yang SS. 2009. A Prediction model for population occurrence of paddy stem borer (Scirpophaga incertulas), based on back propagation artificial neural network and principal components analysis. Computers and Electronics in Agricultur 68:200-206. doi: http://dx.doi.org/10.1016/j. compag.2009.06.003.

Yonow T, Zalucki MP, Sutherst RW, Dominiak BC, Maywald GF, Maelzer DA, Kriticos DJ. 2004. Modelling the population dynamics of the Queensland fruit fly, Bactrocera (Dacus) tryoni: A cohort-based approach incorporating the effects of weather. Ecological Modelling 173:9-30. doi: http://dx.doi.org/10.1016/S03043800(03)00306-5. 